\title{
IDENTIFICATION OF A LOCAL PROBIOTIC BACTERIUM USING 16S rRNA GENE SEQUENCE THAT WAS USED FOR FIELD TRIAL TO ENHANCED WHITELEG SHRIMP (Litopenaeus vannamei) SURVIVAL
}

\author{
Tb. Haeru Rahayu") and Ketut Sugama") \\ ") Department of Aquaculture, Jakarta Fisheries University \\ ") Center for Aquaculture Research and Development
}

(Received 4 Februari 2015; Final revised 19 August 2015; Accepted 10 November 2015)

\begin{abstract}
The use of local probiotics in the culture of aquatic organisms is increasing with the demand for more environmental-friendly aquaculture practices. The local bacterium isolate considered as a probiotic was added into the water of whiteleg shrimp (Litopenaeus vannamei) culture in a field trial. Four rectangular plastic ponds (ca. $20 \mathrm{~m}$ x $30 \mathrm{~m}$ per pond) were used for 100 days experimentation for six consecutive crops in two years experiment. Survival, harvest size, feed conversion ratio (FCR) and Vibrio bacterial count was compared with those of shrimp receiving and none of local isolate. Identification based on 16S rRNA gene sequence shown those isolate was Bacillus pumilus strain DURCK14 with 99\% homology. Water shrimp pond added a local isolate had significantly higher survival at about $10.0 \%$ to $11.7 \%$ than shrimp without added the isolate $(\mathrm{p}<0.05)$, and better FCR, but no significant different in shrimp harvest size. Vibrio bacterial was undetected by total plate count. Moreover, it shown better projected yields on an annual basis (three crops per year).
\end{abstract}

KEYWORDS: $\quad$ shrimp pond, Litopenaeus vannamei, local probiotic, Bacillus pumilus, Vibrio, survival rate, harvest size, FCR

\section{INTRODUCTION}

Microbes are being considered as both beneficial and detrimental roles in aquaculture ponds (Rheinheimer, 1992; Laurencin \& Vigneulle, 1994; Valiela, 1995; Moriarty, 1997). On the beneficial side, they are important and essential components for the nutrient and elemental cycling required to maintaining water quality suitable for cultivation (Valiela, 1995; Moriarty, 1997). Conversely, bacteria and viruses can cause serious disease problems, with viral pathogens having the most serious economic impact on shrimp farming. White spot syndrome virus (WSSV), Taura Syndrome Virus (TSV), and Vibrio harveyi (cause of luminescent bacterial disease) are the three pathogens that account for the majority of losses in Indonesia shrimp culture by causing sudden and massive shrimp mortality (Flegel et al., 1992; Spaargaren, 1996; Lightner \& Redman, 1998).

\# Correspondence: Department of Aquaculture, Jakarta Fisheries University. Jakarta Selatan 12520, Indonesia, Indonesia.

E-mail: ketut_sugama@yahoo.com
Successful shrimp culture requires a combination of factors, including larvae free from pathogens, application of nutritious feeds, physical exclusion of disease organisms and maintenance of proper aeration and suitable pond water quality (Boyd, 1998). Prophylactic, probiotic microbes are now being used widely for treatment of poultry, swine and other land animals to protect against pathogenic microbes (Fuller, 1997; Holzapfel et al., 1998). It is now being applied too in aquaculture and believed can improve the survival and growth (Staley \& Stanley, 1986; Gatesoupe, 1999; Verschuere et al., 2000).

We previously isolated the local bacterium and demonstrated its probiotic properties with whiteleg shrimp Litopenaeus in small laboratory aquaria (Rahayu, 2009). L. vannamei receiving of a proper bacterium in the water had better survival after bacterial challenge tests and showed a high immune response compared with control shrimp without administered of Bacillus (Rahayu, 2009). Here we described field trials in earthen ponds in order to test efficacy of T28 isolate in conditions of commercial grow out ponds. 


\section{MATERIALS AND METHODS}

\section{Bacterium}

Isolate T28 was taken from Jakarta Fisheries University culture collection (JFUCC). It was previously isolated from gastrointestinal tract of Litopenaeus vannamei and demonstrated its efficacy as a probiotic for $L$. vannamei in laboratory trials (Rahayu, 2009). The isolate maintained in marine agar and stored at $4^{\circ} \mathrm{C}$ and were grown in medium tryptic soy broth (TSB) for 24 hours at $30^{\circ} \mathrm{C}$. The incubated isolate was mixed with sterilized fine bran and formed of pellets using pellet machine. The amount of isolate was determined by standard solution McFarland No. $6(1.8 \mathrm{x}$ $10^{9} \mathrm{cfu} / \mathrm{mL}$ ). Culture purity and identity were routinely checked during preparation by monitoring the unique and specific physical appearance of isolate on tryptic soy agar (TSA) (Rengpipat et al., 1998).

\section{Pond Trial 1}

Hatchery-reared Litopenaeus vannamei of 0.01-0.02 $\mathrm{g}$ body weight were stocked into four $(20 \mathrm{~m}$ x $30 \mathrm{~m})$ mini shrimp pond at 100 shrimps per $\mathrm{m}^{2}$. Ponds were lined by high density polyethylene plastic with $90 \mathrm{~cm}$ depth. Salinity was $22 \%$ at first crop, in January 2012 and increased to 24\% at second crop in April and eventually 25\% in third crop in August 2012. Water aerated using two units of $1 \mathrm{HP}$ paddle wheel. All shrimps were fed four times daily at $15 \%$ body weight at first month, and 3\% body weight on the next following months. Treated shrimp pond (three ponds) received routine administration of a local isolate probiotic which was added into the water culture every other days at a concentration of $1 \mathrm{mg} / \mathrm{L}$ since the beginning at first stocking continuously until the end of the trial (100 days), and none for the control. Shrimp survival and weights were measured every 10 days beginning at Day $50^{\text {th }}$ by random sampling using lift net to check the shrimp health and feed determination. During the trial, water temperature and $\mathrm{pH}$, were measured daily, while salinity, dissolved oxygen, ammonium, nitrite, nitrate, and alkalinity were measured every 10 days starting day 50 as described by Rengpipat et al. (2000). Total plate count was done at beginning and the end of the culture to examine the standing of Vibrio bacteria (van Stappen, 2006). There was no water exchange during the trial, except adding the fresh water due to evaporation.

\section{Pond Trial 2}

Conditions were nearly identical to those in Trial 1 with respect to shrimp stocking densities, tested parameters, feeding, monitoring, and experiment phase.

\section{Molecular Isolate Identification}

This step was initiated by preparation isolate for DNA isolation and template DNA for PCR. Isolate was grown in medium of marine agar (Difco) and incubated at $30^{\circ} \mathrm{C}$ to log phase stages for 48 hours. Template DNA was prepared by boiling method (Sjamsuridzal \& Oetari, 2003). Amplification of $16 \mathrm{~S}$ ribosomal RNA gene followed PCR protocol of Yuwono (2006) using universal bacterium primer, Escherichia coli bacterium in the position $9 \mathrm{~F}$ and 1510R. Electrophoresis of PCR products was done according the protocol described by Lightner (1996) and visualized by using the gel documentation ultra violet trans-illuminator. Next following step was purifying PCR products by ethanol precipitation method and sodium acetate to remove excess primer. Suspended RNA, as a template RNA was used for cycle sequencing reactions followed procedures of Applied Bio Systems Inc., consisting of the big dye terminator ready reaction. Amplification product was purified to remove excess dye, primary, and minerals using ethanol precipitation method before sequenced. The last step, $16 \mathrm{~S}$ ribosomal RNA gene sequence obtained was compared with the database of Gen-Bank using the Basic Local Alignment program Search Tool (BLAST) (Macrae, 2000) to obtain the identity of bacterium isolate (Saitou \& Nei, 1987; Holmes, 2003).

\section{RESULTS AND DISCUSSION}

Whiteleg shrimp (Litopenaeus vannamei) added by local isolate T28 had significantly higher survival (Figure 1), i.e. $96.3 \%$ (first year/trial 1) and $95.7 \%$ (second year/trial 2) respectively compared to $85.7 \%$ and $84,0 \%$ respectively for the control. Significant survival differences began at day 60 after the start of both trials (Figure 2). After 100 days, mean individual weights (Figure 3) of the treated shrimp were $16.69 \pm 0.1 \mathrm{~g}$ and $16.67 \pm 6.1 \mathrm{~g}$ respectively. Meanwhile the control were $16.84 \pm 0.1 \mathrm{~g}$ and $16.84 \pm 0.1$ respectively and showed no significant difference to the probiotic treatment $(\mathrm{P}>0.05)$. This represents a $10.6 \%$ and $11.7 \%$ higher survival than the control for Trial 1 and Trial 2, respectively. Projected yields per crop were 964.34 $\mathrm{kg}$ and $957.19 \mathrm{~kg}$ for treated pond in Trial 1 and Trial 2, respectively, and $865.91 \mathrm{~kg}$ and $848.73 \mathrm{~kg}$ for the controls in both trials.

The ammonium, nitrite, and nitrate concentrations in the treated ponds were about at maximum value of $0.05,0.25$, and $1.0 \mathrm{mg} / \mathrm{L}$ respectively for both trials, whereas the non-treated ponds shown over the standard limit i.e. $1.5,1.3$, and $3 \mathrm{mg} / \mathrm{L}$ respectively for both trials. The $\mathrm{pH}$ ranged from 7.4 to 7.8 respectively for treated ponds in Trial 1 and Trial 2 com- 


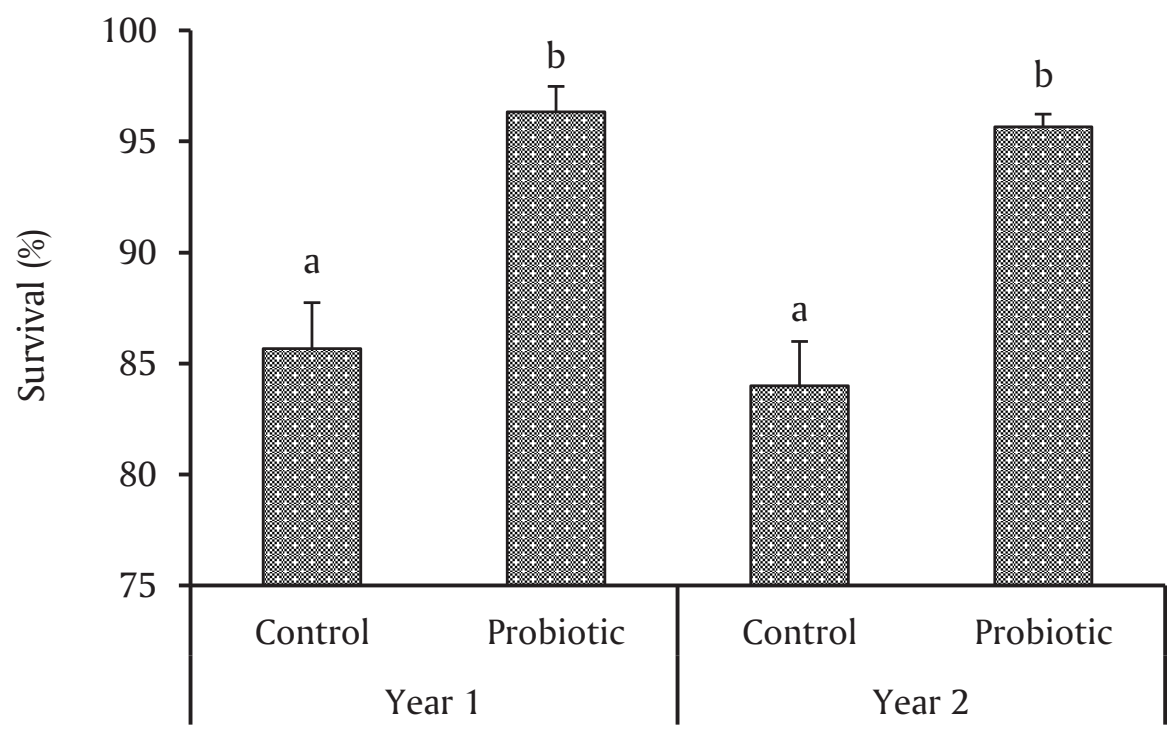

Figure 1. Shrimp survival (100 days culture) during the experiment
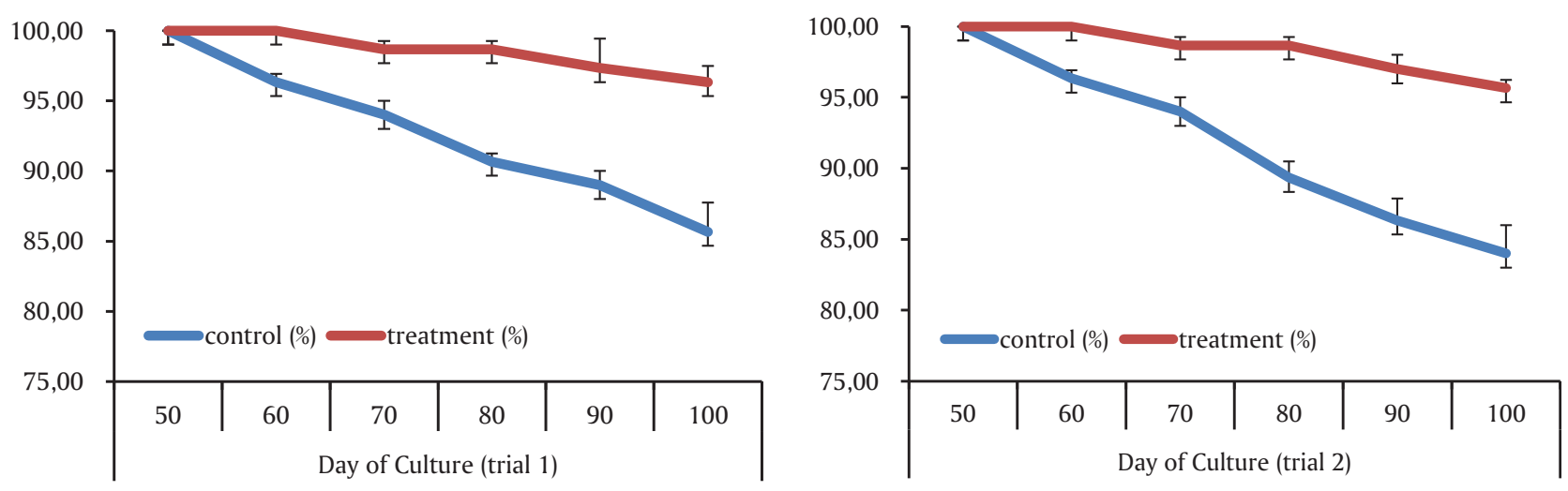

Figure 2. Shrimp mortality (100 days culture) during field experiment

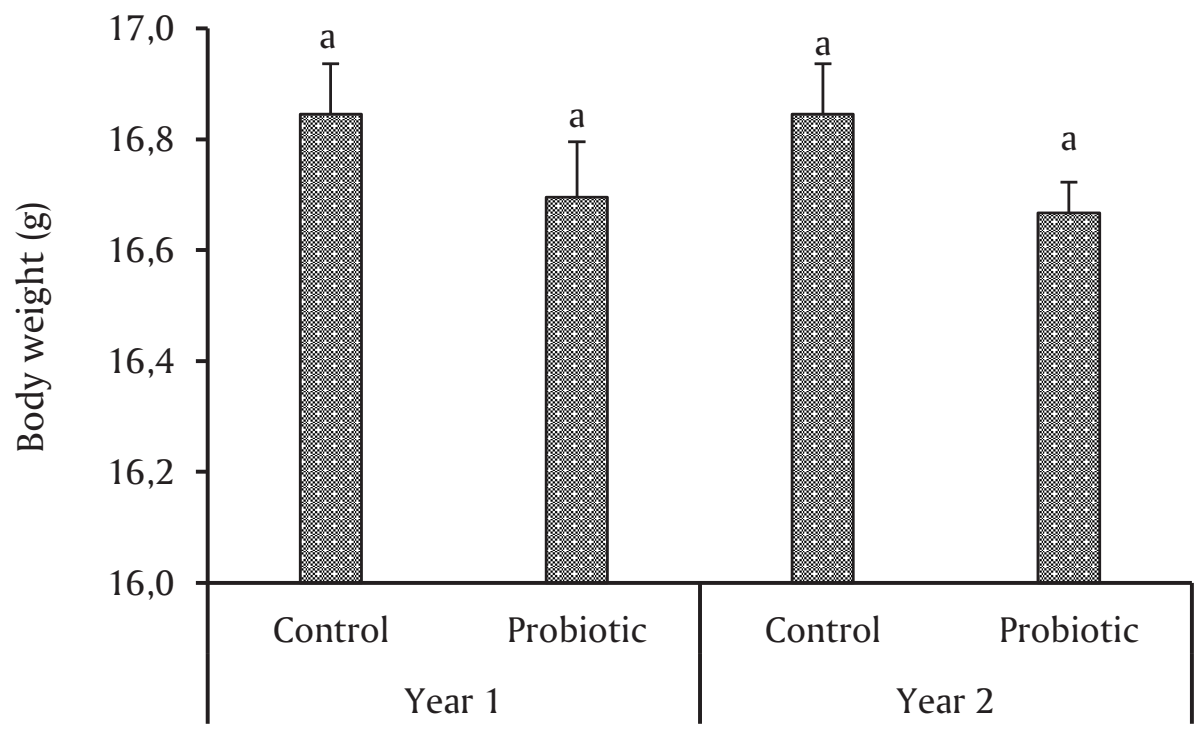

Figure 3. Individual shrimp body weight (100 days culture) during experiment 
pared to 7.0 to 8.0 respectively for non-treated ponds during both trial. Whereas, water temperatures and other water quality values were essentially the same between ponds in each trial. Water temperatures ranged from $27^{\circ} \mathrm{C}$ to $30^{\circ} \mathrm{C}$, respectively, for Trial 1 and Trial 2 . Salinity ranged between $2{ }^{\circ} \mathrm{C}$ and $4 \%$ for Trial 1 and Trial 2. Dissolved oxygen from both trials was never less than $4.0 \mathrm{mg} / \mathrm{L}$ during the day and night and total alkalinity ranged from 95 to $140 \mathrm{mg} / \mathrm{L}$ for both trials. Total plate count on Vibrio (Figure 5) was not detected on treated pond, while the control was about $1.0 \times 10^{3} \mathrm{cfu} / \mathrm{mL}$.

Feed conversion ratio showed linear result that indicated a better value on treated pond (Figure 4) i.e. $1.28 \pm 0,03$ and $1.26 \pm 0.04$ as compared to $1.48 \pm 0.03$ and $1.49 \pm 0.04$ respectively for the control. This indicated a $15.62 \%$ to $18.25 \%$ more efficient use of feed in the probiotic treatments.

BLAST analysis showed that the isolate was from genus Bacillus. The species was Bacillus pumilus strain DURCK14 with $99 \%$ homology.

These results indicated that the benefits of a $\mathrm{Ba}$ cillus pumilus supplementation seen in laboratory tests (Rahayu, 2009) could also be obtained in field trials conducted under normal commercial farming conditions. Bacillus known is the type of bacteria used for probiotics in aquaculture (Verschuere et al., 2000; Rengpipat et al., 2000; Balcazar et al., 2006; Geovanny et al., 2007). The genus of Bacillus is considered as cosmopolitan bacteria (can live in many areas). Bacillus has wide physiological tolerance to heat, acidity, and salinity (Holt et al., 1994). Bacillus pumilus was

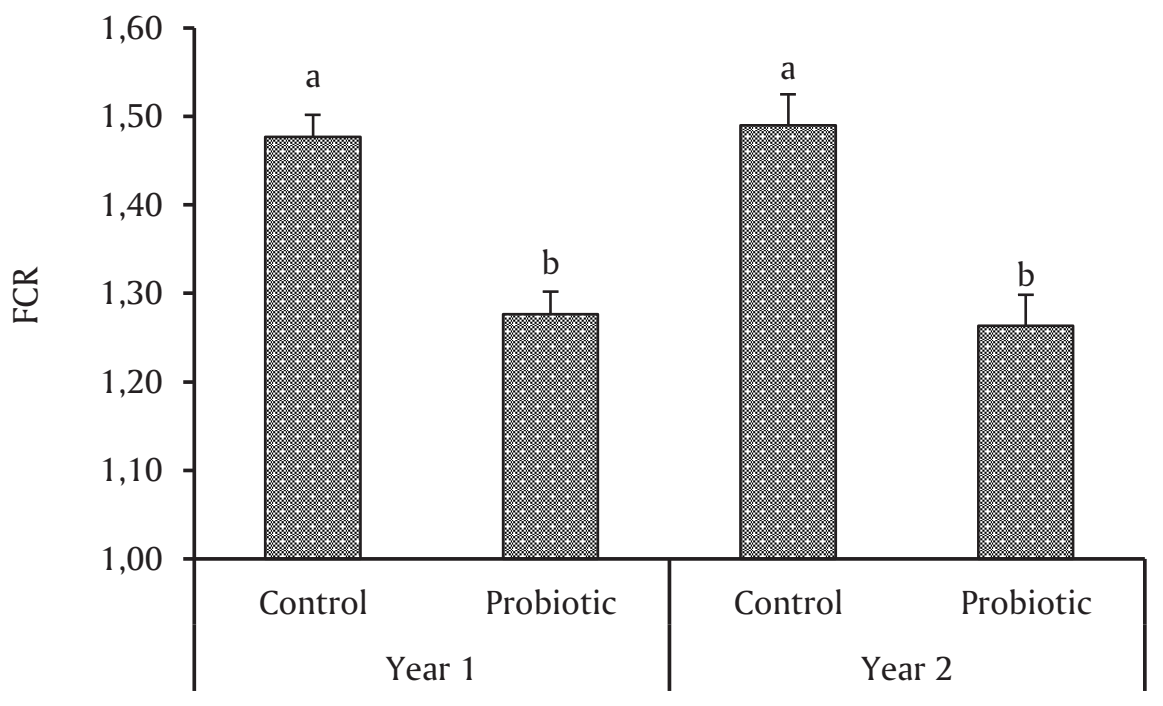

Figure 4. Feed conversion ratio (FCR) of shrimp (100 days culture) during experiment

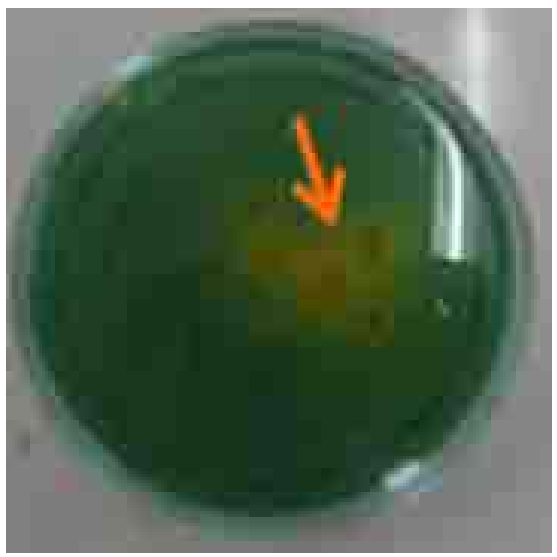

Figure 5. Presenting of Vibrio on un-treated pond at the end of the shrimp culture (arrow shown Vibrio colony after 24 hours incubation) 
considered having performance as mentioned above during the experiment as can be seen by the better production performance.

Better shrimp survival and no different on shrimp size showed that Bacillus pumilus managed on maintaining the water quality in 100 days experiment. This bacterium predicted conducting the nitrifying cycle and converting the organic matter into the tolerable matter (Verschuere, 2000). Whereas in control ponds where no bacterium was added, showed some increase in ammonia, nitrite, and nitrate concentrations. Stress can increase the shrimp susceptibility to pathogens even in low virulence (Song et al., 1993) and indeed suppressed the shrimp survival.

In addition, the effectiveness of Bacillus pumilus addition was not only considered as physical and chemical water purifier agent water, however, it supported the biological aspect as well, especially the microbial performance on the water (Verschuere, 2000). Bacillus, in general, can suppress the Vibrio population in the water (Marques et al., 2006). It was very important, since Vibrio is considered as opportunistic bacteria that may be pathogenic in shrimp culture (Balcazar et al., 2006). Bacillus was considered to be able to compete with the Vibrio sp. for chemicals, nutrients, and space (Verschuere et al., 2000; Geovanny et al., 2007; Rengpipat et al., 2003).

\section{CONCLUSION}

In conclusion, Bacillus contribution was not only improved the water quality, but also improved the shrimp performance and indeed improved the metabolism performance as well. Shrimp shown a more efficient on feed given during the trial.

\section{ACKNOWLEDGEMENT}

This research was supported by the internal undergraduate Scholarship of Jakarta Fisheries University and partially supported by Center of Education of Agency for Marine and Fisheries Affairs Human Resources Development (AMFHRD).

\section{REFERENCES}

Balcázar, J.L., de Blas, I., Zarzuela, I.R., Cunningham, D., Vendrell, D., \& Múszquiz, J.L. (2006). The role of probiotic in aquaculture. Veterenary Microbiology, 114, 173-186.

Laurencin, B. F., \& Vigneulle, M (1994). Diseases in aquaculture operations. In Barnabé, G. (Ed.), Aquaculture biology and ecology of cultured species. Ellis Horwood, New York, p. 373-390.

Boyd, C.E. (1998). Water quality management for pond fish culture. Elsevier. Alabama, 318 pp.
Flegel, T.W., Fegan, D.F., Kongsom, S., Vuthikomudomkit, S., Sriurairatana, S., Boonyaratpalin, S., Chantanachookhin, C., Vickers, J.E., \& Macdonald, O.D. (1992). Occurrence, diagnosis and treatment of shrimp diseases in Thailand. In Fulks, W., \& Main, K.L. (Eds.), Diseases of cultured penaeid shrimp in Asia and the United States. The Oceanic Institute, Honolulu, HI, p. 57112.

Fuller, R. (1997). Probiotics 2: applications and practical aspects 1st Ed. Chapman \& Hall, London.

Gatesoupe, F.J. (1999). The use of probiotics in aquaculture. Aquaculture, 180, 147-165.

Geovanny, G.R.D., Balcazar, J.L., \& Shen, M.A. (2007). Probiotic as control agents in aquaculture. A review. Oceanic and Coastal Sea Research, 1(6), 7679.

Holt, J.G., Krieg, N.R., Sneath, P.H.A., Staley, J.T., \& William, S.T. (1994). Bergey's manual of determinative bacteriology. Williams and Wilkins, Ninth edition. Baltimore, Maryland. USA, 754 pp.

Holzapfel, W.H., Harberer, P., Snel, J., Schillinger, U., \& Huis in't Veld, J.H.J. (1998). Overview of gut flora and probiotics. Int. J. Food Microbiol., 41, 85101.

Holmes, S. (2003). Bootstrapping phylogenetic trees: theory and methods. Statistical Science, 18, 241255.

Lightner, D.V., \& Redman, R.M. (1998). Shrimp diseases and current diagnostic methods. Aquaculture, 164, 201-220.

Macrae, A. (2000). The use of $16 \mathrm{~S}$ rDNA methods in soil microbial ecology. Brazilian Journal of Microbiology, 31, 77-82.

Moriarty, D.J.W. (1997). The role of microorganisms in aquaculture ponds. Aquaculture, 151, 333-349.

Rahayu, Tb.H. (2009). Study of local probiotic bacteria to improve the health status of vannamei shrimp Litopenaeus vannamei (boone). PhD. Thesis. Depok. Indonesia.

Rengpipat, S., Phianphak, W., Piyatiratitivorakul, S., \& Menasveta, P. (1998). Effect of a probiotic bacterium on black tiger shrimp Penaeus monodon survival and growth. Aquaculture, 167, 301-313.

Rengpipat, S., Rukpratanporn, S., Piyatiratitivorakul, S., \& Menasaveta, P. (2000). Immunity enhancement in black tiger shrimp (Penaeus monodon) by a probiont bacterium (Bacillus S11). Aquaculture, 191, 271-288.

Rengpipat, S., Tunyanun, A., Fast, A.W., Piyatiratitivorakul, S., \& Menasveta, P. (2003). Enhanced growth and resistance to Vibrio challenge in pond-reared black tiger shrimp Penaues monodon fed a Bacillus probiotic. Dis. Aquat. Org., 55, 169-173. 
Rengpipat, S., Rukpratanporn, S., Piyatiratitivorakul, S., \& Menasveta, P. (2000). Immunity enhancement in black tiger shrimp (Penaeus monodon) by probiont bacterium (Bacillus S11). Aquaculture, 191, 271-288.

Rheinheimer, G. (1992). Pathogens in aquatics plants and animals and their control. In Rheinheimer, G. (Ed.), Aquatic microbiology, 4th Edn. John Wiley \& Sons. Guildford, p. 175-249.

Saitou, N., \& Nei, M. (1987). The neighbor-joining method: a new method for reconstructing phylogenetic trees. Mol. Biol. Evol., 4, 406-425.

Sjamsuridzal, W., \& Oetari, A. (2003). Rapid preparation of fungal and bacterial genomic DNA for PCR. Hayati, 10(3), 122-124.

Song, Y.L., Cheng, W., \& Wang, C.H. (1993). Isolation and characterization of Vibrio damsela infectious for cultured shrimp in Taiwan. J. Invertebr. Pathol., 61, 24-31.

Spaargaren, D.A. (1996). Disease in cultures of tiger prawns, Penaeus monodon Fabricius, 1798. Crustacean, 69, 1018-1024.
Staley, J.T., \& Stanley, P.M. (1986). Potential commercial applications in aquatic microbiology. Microb. Ecol., 12, 79-100.

van Stappen, G. (1996). Artemia. In Lavens, P., \& Sorgeloos, P. (Eds.), Manual on production and use of live food for aquaculture. FAO. Fisheries Technical Paper, 361, 107-137.

Valiela, I. (1995). The carbon cycle: production and transformation of organic matter. In Flegel, T.M. (Ed.), Marine ecological processes, 2nd Edn. Multimedia Asia, Bangkok, p. 385-461.

Verschuere, L., Rombaut, G., Sorgeloos, P., \& Verstraete, W. (2000). Probiotic bacteria as biological control agents in aquaculture. Microbiol. Mol. Biol. Rev., 64, 655-671.

Verschuere, L., Rombaut, G., Sorgeloos, P., \& Verstraete, W. (2000). Probiotic bacteria as biological control agents in aquaculture. Microbiology and Molecular Biology Reviews, 64(4), 655-671.

Yuwono, T. (2006). Theory and application of polymerase chain reaction. ANDI. Yogyakarta, $239 \mathrm{pp}$. 